\author{
Aleksandra Sobańska* \\ (iD) https://orcid.org/0000-0003-3563-0582 \\ Kamila Smyczek ${ }^{* *}$ \\ (iD) https://orcid.org/0000-0003-3432-2836
}

\title{
GENDER INCONGRUENCE IN TRANSGENDER PERSONS: ANALYSIS OF THE AUTHORS' OWN RESEARCH
}

\begin{abstract}
This article presents an analysis of a fragment of a larger study on transgender individuals. In this study, the authors focused exclusively on the experience of gender incongruence; the conflict between gender identity and the gender conferred at birth. In order to clearly explain the scope of this study, the first part of the article presents transgender theories, and those related to identity and gender identity. The second part of the article presents strategies for combatting gender incongruence. These are developed on the basis of the collected empirical material, and through consideration of evidence concerning whether gender incongruence had a significant impact on the formation of the personal and social identity of transgender individuals. The research was based on a qualitative approach, with the main technique employed being a free-form interview. The research was performed throughout the whole of Poland.
\end{abstract}

Keywords: transgenderism, transsexuality, identity, gender identity, gender incongruence, gender transition.

\section{Introduction}

The issues of transgender and transsexuality, as well as the issue of strategies for dealing with gender dysphoria (a mismatch between a person's gender identity and their sex assigned at birth), which are the focus of this article, have been addressed by numerous authors. English-language studies on this subject have been published since the 1990s (e.g. Hines; King, Ekins; Stryker; Stone; Wilchins; Whittle; Devor; Feinberg, etc.), while in Poland the issue of gender identity and adopted strategies was discussed, among others, by Małgorzata Bieńkowska and Anna Kłonkowska in their books: Transseksu-

* MA, Institute of Sociology, Faculty of Economics and Sociology, University of Lodz, ul. Rewolucji 1905 r. 41/43, 90-214 Lodz, Poland, e-mail: ola1994mono@wp.pl

** MA, Institute of Sociology, Faculty of Economics and Sociology, University of Lodz, ul. Rewolucji 1905 r. 41/43, 90-214 Lodz, Poland, e-mail: zarokmozedwa@o2.pl 
alizm w Polsce. Wymiar indywidualny i spoteczny przekraczania binarnego systemu ptci [Transsexualism in Poland: The individual and social dimension of the transgression of the binary gender system] (Bieńkow ska 2012), Transpłciowość - androgynia. Studia o przekraczaniu ptci [Transgender - androgyny: Studies on going beyond gender] (Kłonkowska 2012) or Pteć: dana czy zadana? Strategie negocjacji (nie)tożsamości transpłciowej w Polsce [Gender: A given role or a given task? Strategies for the negotiation of transgender (non-)identity in Poland] (Kłonkowska 2017).

This article focuses on describing the conflict between the social identity, imposed roles and normativity, and the gender identity of a transgender person; their sense of alienation from their own body as well as social norms, as seen by subjects participating in a previously conducted study. In order to address the issue of gender dysphoria, terms such as transgenderism, identity and gender identity need to be defined first.

\section{Transgender, identity, sexual identity: the operationalisation of conceptual notions and processes}

The transgender community is characterised by invisibility. The media promote a distorted image of transgender people by publishing images of drag queens and drag kings ${ }^{1}$, who are perceived as controversial by conformist individuals. In the mainstream social perception, the drag phenomenon is still mockingly described as "playful dressing up", a performance intended to parody masculinity or femininity. In fact, however, in its artistic form drag goes beyond gender dualism, attempting to expose cultural constructs of gender performativity, which has little in common with cabaret (Łojas, Dynarski 2010: 46-48). However, presenting transgender people on the basis of accounts from drag queen and drag king performances leads to a stereotypical, erroneous definition of transgender, which leads to the prevalence of opinions that are inconsistent with scientific knowledge concerning transgenderism. For those unfamiliar with transgender issues, the need for gender reassignment may seem like a whim or a caprice. In fact, it derives from a deeply experienced conflict between one's gender identity and the gender assigned at birth, which transgender people solve through a long and costly process of gender transition.

The terminology used to describe the phenomenon of gender mismatch, i.e. a conflict between the gender assigned at birth and the actual gender identity, has evolved over the years. The term "transsexualism" appeared for the first time

${ }^{1}$ An artistic performance by a male person (drag queen) or a female person (drag king). In their performance, drag queens depict a woman in heavy make-up, dressed in a spectacular woman's outfit (Mizielińska, Stasińska 2014: 94-97). The opposite of a drag queen is a drag king, which is a male character played by a woman (Majka-Rostek 2010: 7). 
in 1980, in the third edition of DSMIII (Diagnostic and Statistical Manual of Mental Disorders), in the category of gender identity disorders. In the older edition, the terms closely associated with transgender included "transvestitism" as a sexual deviation. However, the International Classification of Diseases (ICD) is more widely used, and in June 2018 the ICD-11 announced that transgender would be removed from the list of gender identity disorders, along with the terms "transsexualism" and "sexual dysphoria". Instead, they would be replaced by the term "transsexuality" and "gender incongruence" (WHO 2018).

Another term that is currently used is "transsexuality", which has been replacing "transsexualism", which was commonly used in the past. This is an effect of the activity of LGBT+ organisations and activists ${ }^{2}$, who have pointed out that the postfix "-ism" is associated with diseases or disorders. In turn, "transgender" naturally replaces all terms with the prefix "trans" that end with "sexuality" or "sexualism". For example, homosexuality refers to individuals who feel attracted to individuals of the same sex (Boczkow ski 2009: 20). This means that "sexuality" is associated with sexual desire and the sex drive, while transgender people do not feel attracted to transgender persons, as potentially suggested by the combination of "trans" and "sexuality". One of the subjects of our study described it this way: One shouldn't say that because it's a stupid phrase. To me, transsexualism sounds like homosexualism. It's as if I was attracted to trans people. Maybe it sounds different in England, but not necessarily in Poland. The word "sex" means gender, so it should be transgender (R3).

In the scholarly literature, one can find a distinction indicating that "transgender" is a broader "umbrella term" covering, among others, transsexual persons who strive for gender reassignment, as well as cross-dressers who limit themselves to self-expression through clothing (Kłonkowska 2017: 13). Unlike transvestites, cross-dressers are all those who wear clothes considered to be suitable for the opposite sex: drag queens and drag kings, transvestites, actors, etc. (Klosow 2019: 34). Moreover, the semantic scope of the term "transgender" includes the whole spectrum of non-binary identities: multi-gender, dual-gender, liquid identities, persons who do not feel either male or female, those who strive for partial or total gender reassignment, or non-binary individuals who do not feel the need to start the transition process (Ziemińska 2018: 131). One example

2 The first two letters, L and G, stand for lesbian and gay. Gays and lesbians are homosexual persons, which means that they are sexually attracted only to people of the same sex. The next letter in the acronym LGBT+ is B, which stands for bisexual persons. For bisexuals, sex is not relevant in intimate relationships. Such persons may live in a relationship with a man or woman, regardless of their own gender. The acronym ends with the letter T, i.e. transgender persons (Boczkowski 2009: 20). LGBT+ also has a longer, extended version: LGBTQIQAF, where Q stands for queer, I for intersexual (people who are still looking for their sexual orientation and are not sure of it), Q for questioning, A for ally and F for family and friends. Queer is a broader concept and an umbrella term used to describe all the aforementioned groups (Makuchowska 2011: 11). 
of a non-binary person is Robert, presented by Sarah Davidmann in her article Beyond Borders: Lived Experiences of Atypically Gendered Transsexual People. Robert has removed his breasts and takes testosterone, but has deliberately decided not to perform genital surgery. In a conversation with Davidmann, he described himself as masculine, but for him this is not synonymous with being a man. His non-binary identity goes beyond the dichotomous division into female or male sex (Davidmann 2010: 196-198).

According to the literature, and especially medical terminology, the participants of the study discussed in this article are transsexual persons who define their sex in a binary way: male or female. Despite this fact, the interviewees were not in favour of being described as "transsexual". Taking their preferences into account, the authors of the study decided to use the term "transgender/ism" [Polish: transpłciowość], which becomes the only correct term in NGOs working on behalf of transgender minorities and the individuals these terms refer to. For this reason, the authors decided against using the term "transsexuality" in this article.

Transgenderism continues to be referred to as "gender identification disorder", which is manifested by the incompatibility between the gender assigned at birth and biological sex before reassignment and the gender identity felt by the transgender person (Bieńkowska-Ptasznik 2002: 147). A change in appearance, gender transition ${ }^{3}$, hormonal therapy ${ }^{4}$, full or partial gender reassignment ${ }^{5}$ as well as the legal correction of documents and birth records ${ }^{6}$ becomes a deeply

3 Transition/ gender transition is a term used in relation to transgender people and refers to a transition period between one situation and the other. It covers everything that happens from the moment one discovers one is transgender and makes a decision about gender reassignment up to the completion of gender reassignment. Gender transition is a long-term, multi-stage process. It consists of socio-cultural, medical, psychological and diagnostic aspects (Bieńkow ska 2012: 151).

${ }^{4}$ In the case of transgender men who make the transition from woman to man, hormone therapy is based on taking the right doses of testosterone. Menstruation usually ceases after four months, followed by the appearance of facial hair, thicker body hair, muscle growth and clitoris expansion. Transgender women receive estrogen and progesterone during hormone therapy. This inhibits the production of testosterone, helps male hair and muscles disappear, and assists the reduction of testicles. There is also a significant increase in adipose tissue around the breast and hips (FajkowskaStanik 2001: 57).

${ }^{5}$ Gender reassignment has a narrower meaning than gender transition and consists of two main stages. The first one is the start of hormone therapy, and the second one is surgical gender reassignment. Not all transgender persons decide to undergo a full procedure, for example by forgoing the sex reassignment surgery (SRS), increasingly referred to as gender confirmation surgeries (Breska-Kruszewska, Rachoń 2014: 167-168).

${ }^{6}$ In Poland, legal gender reassignment takes place through court proceedings under Article 189 of the Code of Civil Procedure (CCP). Such cases qualify as cases concerning nonmaterial rights, so the proceedings take place at the regional court. Pursuant to the CCP, the claimant and the defendant must be indicated. In this case, the defendants are the parents of the transgender person on the grounds of wrongful gender assignment of their child at birth. Court proceedings are the only legal way in Poland for an individual to change their birth certificate (Grodzka, Podobińska 2012: 203). 
experienced need for transgender individuals because of the experienced gender dysphoria (Jabłońska, Knut 2012: 24). Speaking of transgender (or, more precisely, transsexual) persons, one can distinguish between trans men, or F/M (female-to-male) men with a male gender identity, and trans women, or M/F (maleto-female) women with female gender identity (Kłonkowska 2017: 13-14).

Another concept that needs to be clarified in order to address gender dysphoria is identity. In the light of the existing literature, identity is an individual's self-definition, an image of oneself created as a result of self-perception, selfobservation and the accompanying emotions (cf. Bokszański 1989: 5-6; Connell 2013: 178; Bieńkowska-P tasznik 2002: 148-149; Kryszk, Kłonkowska 2012: 225). Constructed in this way, identity is characterised by continuity, cohesion and distinctiveness, which means that we constantly feel that we are the same person with a unique, well-established living style, despite the changes in our lives (Geron 2002: 168). The subjective sense of existence boils down to the category of personal identity and one's own self, confronted daily with our objective social identity, which consists of our social roles, social norms, a system of values, background, etc. (Waszyńska, Rękoś 2004: 213-214). Personal identity comprises the most specific features of an individual that distinguish that person from others, while social identity is characterised by features that stem from one's belonging to a particular community. When we explore ourselves, we compare our behaviour with that of other people who belong to the same culture and group (Waszyńska, Rękoś 2004: 213-214). Zbigniew Zaborowski distinguished three models of identity, which comprises: social elements (position, background, social roles), anthropological elements (gender, age), cultural and ideological elements (system of values, upbringing). The combination of these three, or the social identity and personal identity described above, make up the full human identity and remain in close connection with one another (Rawa-Kochanowska 2011: 37).

In the sphere of identity, transgender people do not represent "an exception to the rule". They have the same continuous and coherent identity both before transition and after full gender reassignment. However, because of socialisation and social norms, since their early childhood such people have felt "torn" between their own self and things that are normatively desirable in society (Bieńkow skaPtasznik 2002: 148-149). Socialisation has a significant impact on shaping identities. Primary socialisation, which takes place within the family, teaches, among other things, the values, norms and rules adopted in the family group, and the child accepts them uncritically. During both primary and secondary socialisation, children learn about the behaviours and customs of society, which helps them to internalise the existing social norms (Nikitorowicz 1999: 271-273). Thus, children who deviate from normativity are often misunderstood and rejected by their social circle, which prevents them from living in harmony with themselves if this calls for the rejection of existing social roles (Rawa-Kochanowska 2011: 88). 
Participants involved in primary and secondary socialisation, i.e. the immediate family and the broader social circle, have a significant impact on how a child's gender identity will develop. Gender identity is the sense of being male or female, usually in harmony with biological sex, which confirms the conscious sense of belonging to a specific sex (Świder, Winiewski 2017: 7). In full families, formed by a woman and a man, the mother and the father are the first role models of femininity and masculinity for the child, as well as a source of gender stereotypes and existing gender roles. When observing their parents, children usually identify their gender with the one who has the same biological sex (Rawa-Kochanowska 2011: 51-54). The identity of non-schematic and non-typical individuals is shaped in a somewhat different way. This applies, inter alia, to transgender people, whose gender identity does not coincide with that of the assigned gender, and to nonbinary people who have the gender identity characteristics of a woman and a man (Rawa-Kochanowska 2011: 40).

In the standard situation, a person's biological sex, which is observable on the outside, is consistent with their gender identity, i.e. the internal experience of sexuality. Gender, which is characterised by the gender roles adopted in a particular culture, gives an equilibrium to gender identity and the fullness of a male or female ego (Ciaputa 2011: 429-431). A child acquires knowledge about gender identity and gender roles in three stages. At the first stage, the child is assigned to a specific gender. Then the child consciously perceives the continuity of their gender and realises that they will be a woman or a man in the future. This leads to the notion of gender constancy, which means that no action, behaviour or clothing will change one's gender identity (Rawa-Kochanowska 2011: 28).

Schools and peer groups constitute other important environments for children, and both have a significant impact on how the child's social identity develops. The teacher becomes another model of masculinity or femininity and, moreover, teachers have different expectations towards boys and girls, unintentionally instructing students about the gender stereotypes that are socially accepted. Another example includes textbooks that contain explicit and hidden messages about socially desirable beliefs concerning, among others, those related to genderspecific behaviour (Rawa-Kochanowska 2011: 83-88). A child who deviates from socially defined normativity is often misunderstood and rejected by the surrounding people, who do not allow the child to live in harmony with themselves if this requires the rejection of existing social roles (Rawa-Kochanowska 2011: 88). Moreover, cisgender children, i.e. those whose gender identity is consistent with the gender assigned at birth (Kłonkowska, Dynarski 2017) neither know nor understand what transgender is. They follow their sexual roles and do not accept the different behaviours of their transgender peers, who grow up with a sense of increasing sexual dysphoria, which reaches a critical level with age, especially during puberty, which is associated with the first menstruation and the appearance of facial hair or breasts (Ciaputa 2011: 429-431). 
This overview of the selected concepts, positions and approaches described in the first section gives some indication of the complexity of the subject-matter. For this reason, it was essential to clarify them, in order to eliminate any ambiguities that might appear when reading the subsequent sections of the present article.

\section{Research methodology}

The authors undertook an analysis of the topic of transgenderism in order to demonstrate the importance of the problem, i.e. the internal conflict experienced by trans men and trans women, reinforced by the lack of acceptance in their social environment. An intolerant society and tabooisation force transgender people to develop certain strategies that could make it easier for them to live in a transphobic reality.

The main objective of this part of the study, the results of which are discussed in the present article, was to learn about the strategies used by our interviewees to cope with gender dysphoria, to explore those strategies and reasons why they are adopted, and to find out how the incompatibility between the gender assigned at birth and gender identity shapes the personal and social identity of a transgender person.

Thus, the analysis was limited to answering four main questions: What kinds of strategies did the participants use to cope with gender dysphoria? Which of the strategies were adopted unconsciously and which ones deliberately? Which strategies were aimed at denying the transgender identity of the interviewees, and which ones were aimed at self-expression? What is the impact of being transgender on the personal and social identity of an individual, as seen by the respondents?

The research was qualitative in nature, based on the technique of free-flowing interviews. The interviews were conducted with five $\mathrm{M} / \mathrm{F}$ women and eleven $\mathrm{F} / \mathrm{M}$ men from Cracow, Lodz and Warsaw in 2018-2019. The respondents' average age was 25 (ranging between 19 and 53). Purposive sampling was applied, and the criteria used included age (the respondents had to be of legal age) and the experience of either partial or complete gender reassignment. Two out of sixteen respondents did not declare their willingness to undergo a complete gender reassignment (more precisely, a procedure performed on the genital organs). Contacts to potential respondents who might agree to take part in the study were obtained with the help of a member of Trans-Fuzja, a Polish NGO supporting transgender people, and the Fabryka Równości association in Lodz. The organisations informed their members about the proposed research and additionally posted a related message on their websites and social media. The recommendation of two LGBT + organisations significantly contributed to finding individuals who were willing to participate in the study. Throughout the research procedure, every precaution was taken to ensure that the research remained confidential and anonymous, and did not violate the professional ethics of social researchers. 


\section{Results of the authors' own research analysis: Strategies of coping with gender dysphoria}

The analysis of the empirical material obtained during the interviews enabled the authors to identify the strategies used by the respondents to cope with gender dysphoria. Based on the categorised descriptions of the respondents' experiences and opinions, the researchers identified the following four strategies aimed at the expression of personally experienced gender identity: unconscious, purposeful, self-destructive and intuitive.

The first presented strategy involves intuitive actions towards self-expression in childhood. Rationalisation of the perceived gender mismatch through the belief that everyone shares the same experience is another unconscious action taken by the respondents. Creating a fictitious identity in imaginary worlds; computer games, drawings and comic strips revealed the beginnings of the expression of perceived gender identity, but still not fully conscious at that stage. Individuals who realised that their identity was transgender would often undertake a self-destructive, purposive strategy involving extreme adaptation to the gender role of the gender incompatible with their perceived gender identity. In the case of F/M men this involved, for instance, the exaggerated use of make-up, while in the case of $\mathrm{M} / \mathrm{F}$ women this involved weight training in order to achieve a muscular figure. A less oppressive form of behaviour which nevertheless aggravates gender dysphoria involves the deliberate concealment of one's transgender identity for fear of transphobic reactions in the social environment. The start of the transition process is the last strategy to deal with gender dysphoria, finally used by all research subjects, as presented in the empirical part of the study.

All the participants in the study had already experienced a conflict between their gender identity and gender assigned at birth in their early childhood. This experience initially involved intuitive steps taken in the sphere of self-expression. A transgender child behaved in accordance with the gender identity they experienced, without understanding why they are different from their peers, and this aggravated the sense of being lost. The first experience of gender dysphoria, without being aware of the existence of transgenderism as a phenomenon, put individuals in a situation where they did not have any means of coping with an internal conflict:

Everyone around thought I was a girl. Everyone around me treated me like a girl. However, (pause) I knew perfectly well that something was wrong, but I didn't know how to call it, which gave rise to an internal conflict and a sense of dissonance $-\mathrm{R} 1$.

The aforementioned intuitive actions undertaken in accordance with the perceived gender identity became the first strategy for coping with gender dysphoria. A transgender girl attempted to join a group of girls and a transgender boy tried to join male peers, driven by a strong need. Gender conflicts occurring between chil- 
dren of different sexes became a common barrier in early school years. A transgender child is placed by peers among the gender represented by the child's exterior appearance. With a clear binary gender subdivision in society and at school, characterised by the different ways that boys and girls play, different gender-related expectations, aversion to peers of the opposite sex, a transgender child was placed in a situation where integration with people of the gender compatible with their perceived gender was mostly impossible:

My first such memory dates back to when I was between six and seven. I remember I started getting envious. It was the start of primary school and I started to envy the girls in my surroundings. I was envious about their life and how they were treated, compared to how I was treated. And also, when I tried to integrate with the girls, for example, it was the time when girls say that boys are "yuck" and boys say that girls are "yuck", and there is this division, which started to feel wrong to me a bit. But I really wanted to, I didn't know why and I didn't understand a thing yet, but I really wanted to belong to that social group perceived as girls and integrate with them, and play together. I also wanted to say that boys are "yuck" and that kind of stuff - R15.

The respondents' non-standard behaviours during their childhood were not approved and caused anxiety in their social circle. As a result, attempts were made to convince and force the children to engage in activities compatible with the gender identity assigned at birth and related gender roles. The vast majority of research subjects stated that for many years they struggled with a situation where their loved ones and people in their social circle made constant efforts to force them to conform with the social norms:

In my childhood (...) there were some typical boys' games and then my mom tried to redirect me towards the more girly ones. I bought a bullet gun for myself, and she scolded me and said it wasn't for me. Same story with climbing trees, she said it wasn't appropriate. There were many such behaviours. All my relatives would always say: "You dress like a boy, you act like a boy". Lots of things like this were said in a negative tone - R10.

Actions undertaken by people from the social environment, trying to force a transgender individual to change their gender identity, contradict the concept of gender constancy mentioned in the theoretical section, according to which gender identity cannot be changed by any external interference. Transgender children or transgender adults are helpless in the face of such demands, and the conflict between their gender identity and gender assigned at birth is exacerbated because they lack opportunities for self-fulfilment:

In fact, with me, it started around preschool age, when I began to notice that boys and girls were treated differently and I couldn't come to terms with this because I wanted to have/ play, dress in a typically girly way. Some pink clothes, that kind of stuff, and because of the gender assigned at birth, well, my parents, or the people around me just kept telling me that I couldn't really do it $-\mathrm{R} 8$.

Several interviewees mentioned an attempt to rationalise the problem of gender dysphoria. In the case of the following statement, the interviewee's strategy 
was based on their lack of awareness of them being transgender and of the existence of this phenomenon as such. Within that rationalisation, the interviewee explained to themselves that everyone was struggling with the same problem as experienced by a transgender person and that gender dysphoria was a common experience, affecting a majority of people:

(...) my main memory, something that was stuck in my head, was wondering if everyone had the same thing (laughing). Does everyone have that? And is that normal? I mean, normal meaning natural. I treated it like this, like something in-between, quite natural, you know. I was just wondering if everyone had the same thing - R13.

Due to a rationalisation or lack of awareness, the perceived conflict seemingly ceases to exist. A fully unrealised suppression of the problem allows a transgender person to temporarily adjust their personal identity to the imagined social identity, which is incompatible with the reality. A problem arises when a transgender person discovers the fact of being transgender, thus gaining a completely new perspective on the situation:

(...) I mean, after puberty, I kept thinking that all girls were like that. I lived with this belief for a few years. Then my male and female friends made me realise that it was just me, and that everyone, that girls enjoyed it, and so on, and that I was the only weird person among them. This was actually my first conflict, and back then I didn't even realise it was actually a conflict (...) - R7.

One of the interviewees, after discovering their transgender identity, rationalised the perceived gender dysphoria and treated their breasts as a worthless part of the body, without linking the female breasts with their actual intended use and viewing them as being an attribute typical of the female sex. Ultimately, the attempt to rationalise the problem turned out to be futile and the interviewee decided to undergo a breast removal procedure (mastectomy). In view of the costly surgical procedures which, in the case of genital operations, require a completion of the legal procedure of gender reassignment (Grodzka, Podobińska 2012: 202-204), transgender individuals try to survive that difficult period by rationalising the problem:

Over time, I developed a very serious dysphoria about my breasts. And then I started to treat them just as extra fat. It wasn't so strong anymore/ it wasn't so alien anymore, it was just a bit more fat. Somehow, I got used to it over time - R10.

For the vast majority of respondents, the masculine or feminine sexual characteristics which appear during puberty signalled a strongly aggravating sexual dysphoria. For transgender men, much as for the interviewee mentioned above, the most difficult moment in puberty was the development of breasts, the first menstruation and a feminine voice with an overly high pitch. Transgender women suffered worst because of the awareness of having male genitals, the appearance of facial hair and ever thicker hair all over their body: 
My first period was a horrible thing. I think it was my biggest conflict ever (laughing). (...) During puberty, I got ever more bothered with my unwanted "ballast" because something was already happening here, things started to change, and I got tits and wondered how to get rid of them. That's when the conflict got really worse for me - R12.

Several interviewees, increasingly aware of being transgender, found fulfilment as men or women by creating an alter ego, a fictitious identity in the world of imagination or online. In this strategy, the actual reality became secondary:

(...) I decided to cut myself off from the real world and hide myself in the online world and open up there. Well, you know, it's freedom, you can do just anything, nobody's going to check on you. I just felt safe out there, and I barely existed in the real world, just to be there-R12.

However, despite the growing awareness of being a transgender individual, many interviewees tried to deny their gender identity by attempting to adapt to normative gender roles. Strong pressure from the social circle, which refused to accept these non-normative identities, drove the transgender person to make every effort to internalise the social norms and gender roles adopted as appropriate in their particular culture. In order to prove - to other people and to themselves - that an attempt to match the assigned gender to the expected gender roles may be a chance to overcome the internal conflict, transgender individuals demonstrated their masculinity or femininity in a stereotypical or even exaggerated way:

(...) I was hiding it, hoping that I could somehow overcome it, somehow suppress this aspect of myself. I made various efforts, very stupid ones, to try and to push myself to extremes, to fit the common stereotypes, and extremes. Well, being almost like a "Sebix" [colloquial Polish: a muscular man with a shaved head, dressed in tracksuit bottoms - A.S.]. Well, maybe not that far but, well, I started doing weight training, for instance, hoping that this would help. Well, it didn't work, and things got even worse. My back got too big as a result, not cool at all - R2.

The strategy of suppressing one's transgender identity, as described here, falls within the category of internalised transphobia. Internalised transphobia is a form of oppression, involving self-destructive behaviour. A person who hates being transgender believes that the mismatch between the sex assigned at birth and their gender identity is an illness, and that an attempt to adapt to societal norms may be an effective method to cure it (Kłonkowska et al. 2015: 85-86):

Throughout my time in college, I tried very hard to be a woman, in an incredibly exaggerated way. Very heavy make-up, provocative clothes, corsets to emphasise my waist - it was really caricatural, I mean it... From my perspective, when I think about it now, it was very strange and over the top. On the other hand, now I understand what I was trying to do when I tried so hard to suppress being transgender; by the way, my attending physician said it was simply internalised transphobia. And it stayed like this throughout my time in college - R7.

No strategies to cope with gender dysphoria which involved suppressing the fact of being transgender helped any interviewee to resolve the internal conflict. All the respondents felt alienated from themselves, especially before the start of 
transition. Their personal identity, with transgender identity being a significant element thereof, did not complement their social identity. The decision to start a transition and gradually adjust their exterior appearance to the perceived gender identity was the only effective strategy to overcome the conflict between gender assigned at birth and internally perceived gender identity:

The actual moment, when I started to use male word endings and bought my first binder [a belt to flatten the breasts - A.S.] was last year. You know, I cut my hair short, let my leg hair grow, threw away all my girly clothes and, most importantly, started looking for a sexologist. Well, these were the first changes, really small, but it felt like a great relief! (laughing) - R4.

\section{A conflict between personal and social identity}

A cisgender society that does not accept difference does not make it easy for individuals struggling with gender dysphoria to live a normal life. Transgender people hide their true identity before gender reassignment and in the early stages of transition. Only at the expense of concealing their personal identity can trans men and trans women fulfil the expectations associated with the social identity. This strengthens the sense of self-alienation in transgender persons, mentioned by all the respondents in the interviews:

This was actually said earlier: this was a role that I played, I literally like to compare people to a theatre; it feels as I'm on stage all the time, like a woman in society, but when I finally started to live as a man, I finally felt that I stepped down and came off the stage and finally started living like I would like to live - R7.

The social roles imposed on transgender people, resulting from their gender assigned at birth, lead to a sense of non-unity of the person. Misgendering, i.e. addressing transgender people with names and pronouns that are incompatible with the gender they feel they belong to (Cambridge Dictionary), as well as social expectations inconsistent with gender identity, were experienced by the respondents as unnatural. Unnaturalness and alienation from oneself when playing imposed and unwanted gender roles provides an answer to the question as to whether being transgender leads to a change or modification of personal identity. All the participants in the study unanimously said that they had always felt they were the same person before the transition, and during and after partial or total gender reassignment. Despite the changes, each individual has their own foundation identity, which, in the respondents' opinion, remained unaffected by the transition:

It is often said that when transgender people come out, when they undergo gender transition, they make a 180-degree change, which is not true, because we are the same person all the time, always. It's not that we suddenly get new character traits or lose some of our interests; we really are the same person all the time, only our external skin changes and we finally feel more comfortable - R7. 
Well, identity (pause), I've always had one identity. These were simply appropriate, achievable steps [gender reassignment - K.S.] to make that identity a reality. Oh, and that was it! That's all there is to it $-\mathrm{R} 13$.

In the case of social identity, transgender persons, especially before the start of the transition process, do not have the freedom to express their true self. While fulfilling societal expectations related to the gender roles consistent with the gender assigned at birth, the personal identity of a trans man or a trans woman is constantly camouflaged. From early childhood, transgender persons are allocated to the group of individuals that contradicts their transgender identity. Prior to gender reassignment, the social identity that transgender persons want to identify with is unattainable, which means that the fact of being a transgender person has a significant impact on how their social identity develops.

Hormone therapy, followed by gender reassignment, means that trans men and trans women assume the so-called "passing" (blending), i.e. the appearance that is consistent with the perceived gender. Thanks to the much-wanted "passing", third parties, unaware of the person being transgender, instinctively address that person using pronouns that correspond to his or her gender identity (Kłonkowska 2017: 136-137). After successful gender reassignment, trans men and trans women can fit perfectly into the social model of gender that is in line with their personal identity and thus begin to find fulfilment in the sphere of social identity, often without revealing that they are transgender individuals.

At the moment I'm living in a kind of mode where nobody knows about me. When I graduated from high school, I changed my name, so my name on various student rosters was changed even though I didn't change my documents, so when there is a roll-call or when I arrange some paperwork at the university, this doesn't out me. Nobody has any suspicions. One female friend knows about me, we went to college together, and that's it. I've never lived openly as a trans person, why would I? I am now a woman now for everyone (pause) and that's what it was all about $-\mathrm{R} 8$.

\section{Summary}

When answering the first two questions presented in the methodological part, it should be pointed out that the authors managed to identify the following strategies: 1. intuitive actions towards self-expression in childhood; 2. rationalisation of the perceived gender mismatch through the belief that everyone experiences it; 3 . an escape into the world of imagination by creating a fictitious identity; 4. selfdestructive attempts to adapt to social norms; 5 . less self-destructive behaviours aimed at concealing one's transgender identity; 6 . commencement of the transition process. The first two strategies are characterised by the unawareness of one's own transgender identity. The third one, also used subconsciously, inspired some respondents from our study to undertake the first reflection on their own transgender 
identity and the phenomenon as such. The last three strategies are adopted by fully aware individuals.

Subsequent questions concerning the strategies of dealing with sexual dysphoria focused on either denying one's transgender identity or expressing one's own self. Internalised transphobia in the fourth and fifth strategy is an attempt to deny one's own transgender identity. In the respondents' opinion, this attempt ultimately proves ineffective due to the growing gender dysphoria and the need to combat it. Transgender persons internalised the social norms of society after experiencing a clear rejection upon their attempts at expressing the gender identity they internally identified with. The intuitive aspiration towards self-expression in the first strategy was inhibited, which could have been a reason why the internally perceived gender identity was pursued in hiding (the third strategy). The last, sixth strategy aims at gender reassignment, i.e. transgender individuals strive for a total, fully conscious expression of their self.

What is the impact of an individual's transgender identity on their personal and social identity, as seen by the respondents? Before gender reassignment, transgender people are often put in a situation where they have to choose whether they can freely reveal their personal identity or sacrifice their own self and follow gender roles that are in line with other people's expectations and the social norms. The analysis of the respondents' statements indicates that gender transition is the only effective method to find self-fulfilment and the only effective way to live in accordance with one's own, unchanged personal identity, despite the internal conflict and many changes in the lives of transgender people.

The fact of being transgender does have an impact on social identity. Societal pressure forces transgender people to fulfil social roles consistent with the gender assigned at birth. Trans men and trans women do not have the possibility to fulfil the gender roles matching the identity they internally identify with. Transgender children, who are forbidden to act intuitively, cannot go through their childhood feeling fully themselves. In an intolerant society, transgenderism is not accepted and transgender people usually receive no support from family or friends. Once they have achieved "passing", trans men and trans women have the opportunity to follow their felt gender roles, but they often conceal their past for fear of being misunderstood.

\section{Bibliography}

Bielas J. (2012), Doświadczenie cielesności. Podmiotowe uwarunkowania transseksualizmu, Wydawnictwo Aureus, Kraków.

Bieńkowska M. (2012), Transseksualizm w Polsce. Wymiar indywidualny i społeczny przekraczania binarnego systemu ptci, Wydawnictwo Uniwersytetu w Białymstoku, Białystok.

Bieńkowska-Ptasznik M. (2002), Pteć społeczna-transseksualizm-rekonstrukcja tożsamości, [in:] A. Kuczyńska (ed.), Zrozumieć płeć. Studia interdyscyplinarne, Wydawnictwo Uniwersytetu Wrocławskiego, Wrocław.

Boczkowski K. (2009), Homoseksualizm, Inter Esse, Kraków. 
Bokszański Z. (1989), Tożsamość, interakcja, grupa, Wydawnictwo Uniwersytetu Łódzkiego, Łódź.

Breska-Kruszewska J., Rachoń D. (2014), Medyczne aspekty transpłciowości-rozpoznanie i postępowanie lecznicze, [in:] A.M. Kłonkowska, K. Bojarska (eds.), Psychospołeczne, prawne i medyczne aspekty transptciowości, Wydawnictwo Uniwersytetu Gdańskiego, Gdańsk.

Ciaputa E. (2011), Jak pteć stawała się rodzajem, [in:] K. Slany, B. Kowalska, M. Ślusarczyk (eds.), Kalejdoskop Genderowy. W drodze do poznania ptci społeczno-kulturowej w Polsce, Wydawnictwo Uniwersytetu Jagiellońskiego, Kraków.

Connell R. (2013), Socjologia ptci. Płeć w ujęciu globalnym, Wydawnictwo Naukowe PWN, Warszawa.

Davidmann S. (2010), Beyond Borders: Lived Experiences of Atypically Gendered Transsexual People, [in:] S. Hines, T. Sanger (eds.), Transgender Identities: Towards a Social Analysis of Gender Diversity, Routledge, New York.

Dębińska M. (2015), Prawo, seksuologia a transplciowość. Przemiany społeczno-kulturowych praktyk konstruowania ptci w Polsce (1964-2012), Praca doktorska napisana pod kierunkiem prof. dr hab. A. Wieczorkiewicz, Warszawa.

Dynarski W., Kłonowska A. (2012), Słownik pojęć, [in:] M. Makuchowska, M. Pawlęga (eds.), Sytuacja społeczna osób LGBT. Raport za lata 2010 i 2011, Kampania Przeciw Homofobii, Warszawa.

Fajkowska-Stanik M. (2001), Transseksualizm i rodzina. Przekaz pokoleniowy wzorów relacyjnych w rodzinach transseksualnych kobiet, Wydawnictwo Instytutu Psychologii PAN, Warszawa.

Geron K. (2002), Autodestrukcja u osób transseksualnych, [in:] A. Kuczyńska (ed.), Zrozumieć pteć. Studia interdyscyplinarne, Wydawnictwo Uniwersytetu Wrocławskiego, Wrocław.

Grodzka A., Podobińska A. (2012), Sytuacja osób transpłciowych w Polsce, [in:] A. Kłonkowska (ed.), Transptciowość - Androgynia. Studia o przekraczaniu płci, Wydawnictwo Uniwersytetu Gdańskiego, Gdańsk.

Gruszczyńska A. (2004), Kraków, europejskie miasto homofobów, [in:] Z. Sypniewski, B. Warkocki (eds.), Homofobia po polsku, Wydawnictwo Sic!, Warszawa.

Jabłońska Z., Knut P. (2012), Prawa osób LGBT w Polsce, Kampania Przeciw Homofobii, Warszawa.

Klosow M. (2019), Gender Blending. Praktyki przekraczania kulturowych norm plci, Instytut Wydawniczy Książka i Praca, Warszawa.

Kłonkowska A. (2012), Transpłciowość - Androgynia. Studia o przekraczaniu płci, Wydawnictwo Uniwersytetu Gdańskiego, Gdańsk.

Kłonkowska A. (2017), Płeć: dana czy zadana? Strategie negocjacji (nie)tożsamości transplciowej w Polsce, Wydawnictwo Uniwersytetu Gdańskiego, Gdańsk.

Kłonkowska A., Dynarski W. (2018), Gender i inne kłopotliwe terminy, czyli jak mówić o różnorodności i (nie)normatywności ptciowej i seksualnej, https://jsgll.wordpress.com/2017/09/30/ gender-i-inne-klopotliwe-terminy-czyli-jak-mowic-o-roznorodnosci-i-nienormatywnosci-plciowej-i-seksualnej-anna-klonkowska-wiktor-dynarski/ (accessed 30.10.2019).

Kłonkowska A., Bojarska K., Witek K. (2015), O płci od nowa. Własna tożsamość oczami osób transptciowych, Wydawnictwo Uniwersytetu Gdańskiego, Gdańsk.

Kryszk K., Kłonkowska A. (2012), Sytuacja społeczna osób transpłciowych. Analiza danych $z$ badania ankietowanego, [in:] M. Makuchowska, M. Pawlęga (eds.), Sytuacja spoteczna osób LGBT. Raport za lata 2010 i 2011, Kampania Przeciw Homofobii, Warszawa.

Łojas J., Dynarski W. (2010), Ptciowość (w) drag. Kulturowa tożsamość czy kultura tożsamości?, [in:] P. Szkudlarek (ed.), Przebrani w pteć. Zjawisko drag w kulturze, Wydawnictwo Konsola, Poznań.

Majka-Rostek D. (2010), Drag king jako emanacja kultury późnej nowoczesności, [in:] P. Szkudlarek (ed.), Przebrani w pleć. Zjawisko drag w kulturze, Wydawnictwo Konsola, Poznań. 
Makuchowska M. (2011), Stowniczek pojęć, [in:] M. Makuchowska (ed.), Przemoc motywowana homofobia. Raport 2011, Kampania Przeciw Homofobii, Warszawa.

Mizielińska J., Stasińska A. (2014), Drag king/drag queen, [in:] M. Rudaś-Grodzka (ed.), Encyklopedia gender: pleć w kulturze, Wydawnictwo Czarna Owca, Warszawa.

Nikitorowicz J. (1999), Socjalizacja, [in:] D. Lalak, T. Pilch (eds.), Elementarne pojęcia pedagogiki spolecznej, Wydawnictwo Akademickie Żak, Warszawa.

Queer.pl, Światowa Organizacja Zdrowia: transptciowość nie jest choroba psychiczna, https:// queer.pl/news/201445/swiatowa-organizacja-zdrowia-transplciowosc-nie-jest-choroba-psychiczna (accessed 18.12.2018).

Rawa-Kochanowska A. (2011), Poczucie tożsamości ptciowej w teorii $i$ w badaniach, Wydawnictwo Difin, Warszawa.

Świder M., Winiewski M. (2017), Sytuacja społeczna osób LGBTA w Polsce. Raport za lata 2015-2016, Kampania Przeciw Homofobii, Warszawa.

Trans-Fuzja, Anna Grodzka: nie chodzi o opowiadanie mojej historii, transfuzja.org/pl/artykuly/ newsy/anna_grodzka_nie_chodzi_o_opowiadanie_mojej_historii.htm (accessed 7.11.2019).

Waszyńska K., Rękoś M. (2004), Tożsamość płciowa i czynniki ja warunkujace, [in:] A. Kuczyńska, E.K. Dzikowska (eds.), Zrozumieć płeć. Studia interdyscyplinarne II, Wydawnictwo Uniwersytetu Wrocławskiego, Wrocław.

World Health Organization, https://www.who.int/health-topics/international-classification-ofdiseases (accessed 10.03.2019).

Ziemińska R. (2018), Niebinarne i wielowarstwowe pojęcie płci, Wydawnictwo Naukowe PWN, Warszawa.

\title{
Aleksandra Sobańska \\ Kamila Smyczek
}

\section{NIEZGODNOŚĆ MIĘDZY PLCIĄ PRZYPISANĄ PRZY URODZENIU A TOŻSAMOŚCIĄ PLCIOWĄ U OSÓB TRANSPLCIOWYCH - ANALIZA WYNIKÓW BADAŃ WLASNYCH}

\begin{abstract}
Abstrakt. W artykule zaprezentowane zostały wyniki analizy fragmentu większych badań nad transpłciowością, obejmujących dzieciństwo transpłciowego dziecka, ujawnienie swojej właściwej tożsamości płciowej rodzinie i bliskim, otrzymane wsparcie lub jego brak, przebieg terapii hormonalnej, zabiegów chirurgicznych, procesu sądowego etc. W niniejszym artykule autorki koncentrują się wyłącznie na prezentacji wyników analizy dotyczącej doświadczenia niezgodności płci - konfliktu między tożsamością płciową a płcią przypisaną przy urodzeniu, a zatem przedmiotem analizy uczyniły opinie, wypowiedzi osób transpłciowych doświadczających niezgodności płci. W trosce o czytelność podjętej problematyki w pierwszej części przedstawione zostały stanowiska teoretyczne związane $\mathrm{z}$ transpłciowością, tożsamością oraz tożsamością płciową. W drugiej zaś zaprezentowane zostały strategie radzenia sobie z niezgodnością płciową, opracowane przez badaczki na podstawie zgromadzonego materiału empirycznego. Autorki w prezentacji wyników analizy uwzględniły odpowiedzi na pytania, czy niezgodność płciowa miała znaczący wpływ na kształtowanie się tożsamości osobistej i społecznej osób transpłciowych, uczestniczących w badaniu. Metodologia badania, procedura badawcza oraz analiza osadzone zostały w podejściu jakościowym. Główną techniką był wywiad swobodny ukierunkowany. Teren badań obejmował całą Polskę - w badaniu uczestniczyło 16 osób.

Słowa kluczowe: transpłciowość, tożsamość, tożsamość płciowa, niezgodność płciowa, tranzycja płciowa, korekta płci.
\end{abstract}

